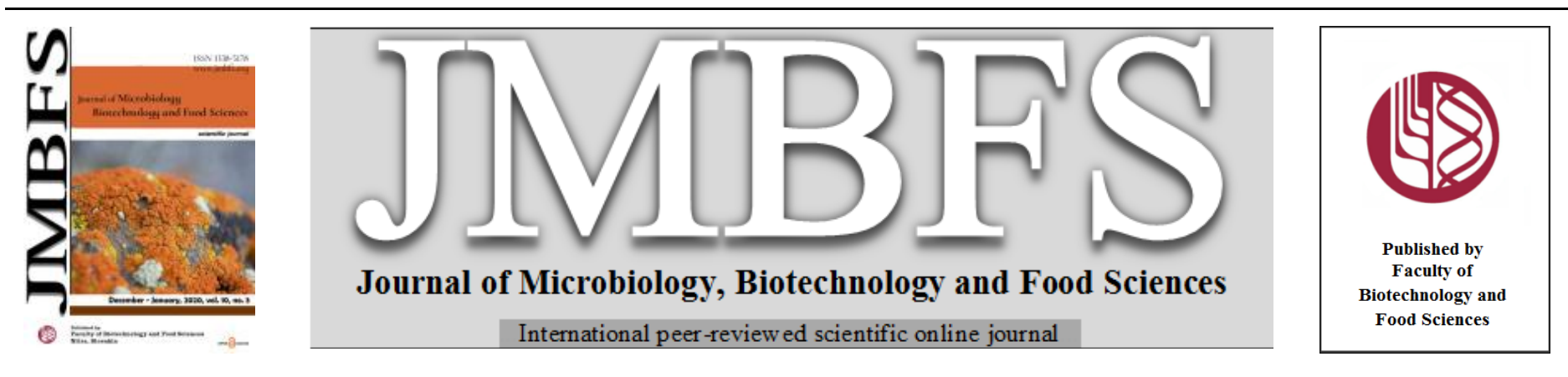

\title{
DETERMINATION OF ANTIOXIDANT, ANTI-AGING AND CYTOTOXICITY ACTIVITY OF THE ESSENTIAL OILS FROM CINNAMOMUM ZEYLANICUM
}

\author{
Warunya Banglao ${ }^{1}$, Acharawan Thongmee ${ }^{2}$, Patamaporn Sukplang ${ }^{2}$, Oraphan Wanakhachornkrai ${ }^{2 *}$ \\ Address(es): \\ ${ }^{1}$ Biomedical Sciences Graduate Program, Department of Medical Science, Faculty of Science, Pathum Thani 12000, Thailand. \\ ${ }^{2}$ Department of Medical Science, Faculty of Science, Rangsit University, Pathum Thani 12000, Thailand.
}

*Corresponding author: oraphan.w@ @rsu.ac.th

doi: $10.15414 / j m b f s .2020 .10 .3 .436-440$

\section{ARTICLE INFO}

Received 23. 12. 2019

Revised 13. 8. 2020

Accepted 23. 9. 2020

Published 1. 12. 2020

Regular article OPEN $\partial_{\text {ACCESS }}$

\begin{abstract}
Antioxidant activity, anti-aging effects and cytotoxicity activity of cinnamon essential oils from Cinnamomum zeylanicum were investigated in this study. The antioxidant activities of the cinnamon essential oil at the concentrations of 125, 250, 500, and 1000 $\mu \mathrm{g} / \mathrm{mL}$ were determined using 2,2-diphenyl-1-picrylhydrazyl (DPPH) and 2,2'-azino-bis (3-ethylbenzo-thiazoline-6-sulfonic acid) diammonium salt (ABTS). The inhibitory activities against collagenase, elastase and tyrosinase were evaluated for anti-aging effects. The antioxidant activity determined by DPPH and ABTS assays varied from $4.91-28.74 \%$ and $4.96-50.17 \%$, respectively. In addition, cinnamon essential oil at all concentrations tested $(100,200,500$, and $1000 \mu \mathrm{g} / \mathrm{mL})$ inhibited tyrosinase activity by 61.68 $93.12 \%$, collagenase activity by $2.83-30.28 \%$ and elastase activity by $4.37-33.92 \%$. The cytotoxicity activity determined by the diphenyltetrazolium (MTT) assay revealed that the cinnamon essential oil at the concentration less than $100 \mu \mathrm{g} / \mathrm{mL}$ did not exhibit cytotoxicity activity on human fibroblast cells while the percentage of cell viability decreased when exposed to this oil at the concentration higher than $150 \mu \mathrm{g} / \mathrm{mL}$. These results demonstrated that the cinnamon essential oil has antioxidant, tyrosinase inhibitory, collagenase inhibitory, and elastase inhibitory activities. In addition, cinnamon essential oil at each effective concentration did not show any toxicity when tested on normal human fibroblast cell. Therefore, this essential oil could be a potential candidate for cosmetic and pharmaceutical products.
\end{abstract}

Keywords: Cinnamon essential oil, antioxidant activity, anti-aging activity

\section{INTRODUCTION}

Skin and its accessory assembled to the integumentary system provide the protection for the body. This barrier prevents our body from microbial infections, retains body fluids, and maintains body temperatures (Yagi and Yonei, 2018). Skin is composed of two main layers, epidermis and dermis. Epidermis rests a top of dermis layer which protects deeper skin layers. Epidermis, the most outer layer of the skin, is directly exposed to UV irradiation and other environmental factors resulting in many skin problems such as spot, wrinkles, acne, rashes, and infections (Mclafferty et al., 2012). The dermis connected to the epidermis through a basement membrane composes of collagen, elastic fibers, and extrafibrillar matrix. Collagen and elastin give the skin elasticity and reduce wrinkles.

In skin aging, the dermis begins to thin due to the loosening of collagen networks and the decreasing elastin fibers. The breakage of collagen and elastin reduces the structure of the dermis and increases the matrix metalloproteinase (MMP) levels that lower the collagen and elastin level (Stevenson $\boldsymbol{e t}$ al., 2007; Farage $\boldsymbol{e t}$ al., 2008). The matrix metalloproteinases (MMP) are a family of calciumdependent and zinc-dependent endopeptidases which excrete from many cell types. Collagenases and elastase, members of the matrix metalloproteinases (MMP) family, can hydrolyze extracellular matrix proteins and lower the collagen and elastin level that cause skin aging. (Farage $\boldsymbol{e t}$ al., 2008). Therefore, skin aging is associated with increased dermal enzymatic activities, including collagenase and elastase. In addition, tyrosinase is an important regulator and the rate-limiting enzyme for melanogenesis. It catalyzes the hydroxylation of Llysine and the oxidation of L-DOPA to o-quinone, which induces the production of melanin pigments. The excessive melanin accumulation leads to human skin disorders, such as freckles and age spots (Chang $\boldsymbol{e t}$ al., 2013). Thus, inhibitors of collagenase, elastase and tyrosinase are important ingredients in cosmetic and medication products to protect skin against hyperpigmentation and aging.

One of the skin deterioration causes is oxidative stress. Several factors such as high exposure to environmental agents, e.g., UV, ozone and pollutants lead to oxidative stress. Sohal and Allan (1990) demonstrated that oxidative stress triggers the genetic program through the modulation of redox sensitive genes and causes skin aging. Since oxidative stress can be reduced by antioxidant compounds, this study aims to search for natural antioxidant compounds that inhibit skin aging and hyperpigmentation.

Many natural products, such as soybean, berry and orange, have been used as beneficial ingredients in several skincare products to promote the protection of skin infections, skin whitening and reducing wrinkles. Since cinnamon has long been used for a long time not only in cooking, but also in-home remedies and medicinal purposes (Gruenwald, 2010), it challenges researchers in the field of skin aging. The health benefits of cinnamon are from essential oils obtained from its bark. As with many components of essential oils cinnamaldehyde exhibits antiviral, antibacterial and antifungal properties (Becerril $\boldsymbol{e t}$ al., 2007; Gende $\boldsymbol{e t}$ al., 2008). In addition, Chou et al. (2013) demonstrated that Cinnamomum cassia oil can minimize the production of melanin and enhance skin whitening.

Thus, due to the significant benefits of cinnamon, it is worth to put much effort into a deeper understanding of cinnamon essential oil- as a natural ingredient that may prevent skin aging and aid in skin whitening. Therefore, this study aims to investigate some in vitro biological activities of cinnamon essential oil from Cinnamomum zeylanicum such as antioxidant, tyrosinase inhibitory, collagenase inhibitory, elastase inhibitory, and cytotoxic activities.

\section{MATERIALS AND METHODS}

\section{Essential oil}

Cinnamon essential oil from Cinnamomum zeylanicum was purchased from a local natural product retailer, Botanicessence, in Bangkok, Thailand. This essential oil was water-distilled (hydro-distillation) extracts. It was made in aliquot's and stored in tightly closed brown glass vials and kept at $4{ }^{\circ} \mathrm{C}$ until analysis. HPLC analysis of cinnamon essential oil revealed that the main constituents of cinnamon essential oil were cinnamaldehyde $(68.80 \%)$, eugenyl acetate $(4.60 \%)$ and caryophyllene $(4.18 \%)$. 


\section{Chemicals and cell culture}

2,2 diphenyl-1-picryl hydrazyl (DPPH), 2,2'-azino-bis (3-ethylbenzthiazoline-6sulphonic acid) (ABTS), 6-hydroxy-2,5,7,8-tetramethylchroman-2-carboxylic acid (Trolox), L-Ascorbic acid, tyrosinase enzyme, and 3-(4,5-dimethylthiazol-2yl)-2,5-diphenyl-2H-tetrazolium bromide (MTT) were purchased from Sigma USA. Dulbecco' modified Eagle's medium (DMEM) medium, fetal bovine serum (FBS), trypsin solution (Gibco, USA), EnzChek ${ }^{\mathrm{TM}}$ collagenase assay kit, and EnzChek ${ }^{\mathrm{TM}}$ elastase assay kit were purchased from Thermo Fisher Scientific, USA. Human fibroblast cells were purchased from American Type Culture Collection.

\section{Antioxidant activity test by DPPH assay}

The antioxidant activity of the essential oil was determined spectrophotometrically as described by Lee and Lee (2010). Briefly, $100 \mu \mathrm{L}$ of the essential oil at the concentrations of $62.5,125,250,500$, and $1000 \mu \mathrm{g} / \mathrm{mL}$ were mixed with $100 \mu \mathrm{L}$ of $0.1 \mathrm{mM}$ DPPH dissolved in methanol. The reaction mixtures were kept in dark at room temperature for 30 minutes. The absorbance of the mixture was measured at the wavelength of $515 \mathrm{~nm}$ and expressed as trolox equivalent antioxidant capacity (TEAC)

\section{Antioxidant activity test by ABTS assay}

According to the protocol of $\mathbf{R e}$ et al. (1999), the ABTS radical cation (ABTS+) were prepared by mixing the ABTS stock solution and potassium persulfate and kept in the dark at room temperature for approximately 12-16 hours before use Then the $\mathrm{ABTS}+\bullet$ solution was diluted with methanol until the absorbance of the solution was $0.70( \pm 0.02)$ at the wavelength of $734 \mathrm{~nm}$. One hundred microliters of the essential oil at the concentrations of $62.5,125,250,500$, and $1000 \mu \mathrm{g} / \mathrm{mL}$ were mixed with $100 \mu \mathrm{L}$ of diluted ABTS + • solution and then incubated in the dark at room temperature for 15 minutes. The absorbance of the reaction mixture was measured at the wavelength of $515 \mathrm{~nm}$ and expressed as trolox equivalent antioxidant capacity (TEAC).

\section{Inhibition of tyrosinase activity assay}

According to Eicken et al. (1998), $100 \mu \mathrm{L}$ of cinnamon essential oil at the concentrations of $10,100,200,500$, and $1000 \mu \mathrm{g} / \mathrm{mL}$ were mixed with $850 \mu \mathrm{L}$ phosphate buffer, $\mathrm{pH}$ 6.8. Then, $50 \mu \mathrm{L}$ of L-Tyrosine and $2 \mu \mathrm{L}$ tyrosinase enzyme were added to start the activity. The assay mixture was incubated at 37 ${ }^{\circ} \mathrm{C}$ for 6 minutes and the absorbance of the mixture was measured at the wavelength of $475 \mathrm{~nm}$. Tyrosinase inhibition activity was expressed as the percentage inhibition of enzyme tyrosinase.

\section{Inhibition of collagenase activity assay}

According to the protocol of EnzChek ${ }^{\mathrm{TM}}$ gelatinase/collagenase assay kit, $80 \mu \mathrm{L}$ of the cinnamon essential oil at the concentrations of 10,100, 200,500, and 1000 $\mu \mathrm{g} / \mathrm{mL}$ were mixed with $20 \mu \mathrm{L}$ of DQ gelatin stock solution. The collagenase enzyme from Clostridium histolytium at the volume of $100 \mu \mathrm{L}$ was added, then incubated at $25^{\circ} \mathrm{C}$ for 90 minutes in the dark. The fluorescence intensity of the mixture was measured by using microplate reader at the excitation wavelength of $485 \mathrm{~nm}$ and emission wavelength of $528 \mathrm{~nm}$

\section{Inhibition of elastase activity assay}

According to the protocol of EnzChek ${ }^{\mathrm{TM}}$ elastase assay kit, $50 \mu \mathrm{L}$ of cinnamon essential oil at the concentrations of $10,100,200,500$, and $1000 \mu \mathrm{g} / \mathrm{mL}$ were mixed with $50 \mu \mathrm{L}$ of DQ elastin solution. The elastase enzyme from porcine pancreatic at the volume of $100 \mu \mathrm{g} / \mathrm{mL}$ was added, then incubated at $25^{\circ} \mathrm{C}$ for 90 minutes in the dark. The fluorescence intensity was measured by using microplate reader at the excitation wavelength of $485 \mathrm{~nm}$ and emission wavelength of $528 \mathrm{~nm}$.

\section{Cytotoxicity assay}

The cytotoxicity assay was performed by using MTT assay. Fibroblast cells were seeded at $5 \times 10^{3}$ cells/well and maintained in a humidified atmosphere with $\mathrm{CO}_{2}$ at $37{ }^{\circ} \mathrm{C}$. The cells were left to adhere for 24 hours before exposing to the essential oil at the concentrations of $10,100,150,200$, and $400 \mu \mathrm{g} / \mathrm{mL}$ for 24 hours. One hundred microliters of MTT solution was added into each well and then incubated for 4 hours. The absorbance was measured by using microplate reader at $570 \mathrm{~nm}$ and expressed as percentage of cell viability.

\section{Statistical analysis}

The data were expressed as means \pm S.E.M. of at least three-independen experiments. The GraphPad Prism version 8.0.2 software was used to analyze the data. The differences between the experimental group were assessed by one-way analysis of variance (ANOVA) followed by Dunnett test. The probability value ( $p$-value) of less than $0.05(p \leq 0.05)$ was considered as a statistically significant.

\section{RESULTS AND DISCUSSION}

Cinnamomum zeylanicum also known as cinnamon has been used for medicine and as an ingredient in Asian food. The oil extracted from Cinnamomum zeylanicum showed antioxidant, antifungal, anticancer, anti-inflammatory, antidiabetes, and antihypertensive capabilities in the previous reports (Nyadjeu $\boldsymbol{e}$ al., 2011; Varalakshmi et al., 2014; Han and Parker, 2017; Gulcin et al., 2019). It is well documented that an active constituent in a plant is varied on the method of extraction. The essential oil has long been commercialized for cosmetics, pharmaceuticals and perfume industries (Shaaban and El-Ghorab, 2012). Therefore, this study aimed to investigate some biological activities of the essential oi extracted from Cinnamomum zeylanicum such as antioxidant, antityrosinase, anti-collagenase, and anti-elastase capabilities of the oil. In addition, in vitro cytotoxicity test was also performed.

\section{Antioxidant activity}

The in vitro antioxidant activities of cinnamon essential oil from Cinnamomum zeylanicum were determined by DPPH and ABTS assay. The cinnamon essential oil at the concentrations of $125,250,500$, and $1000 \mu \mathrm{g} / \mathrm{mL}$ significantly increased the DPPH inhibition percentage by $8.22 \pm 0.70,12.74 \pm 2.48,20.10 \pm$ 1.71 and $28.74 \pm 1.61 \%$, respectively. However, the essential oil at the concentration of $62.5 \mu \mathrm{g} / \mathrm{mL}$ did not significantly increase the percentage of DPPH inhibition when compared with the control groups (Figure 1A). The extent of inhibition of the absorbance of the DPPH• was plotted as a function of the concentration in order to determine the Trolox Equivalent Antioxidant Capacity (TEAC). The cinnamon essential oil at the concentrations of $62.5,125,250,500$, and $1000 \mu \mathrm{g} / \mathrm{mL}$ showed the TEAC values as $0.58 \pm 0.11,1.84 \pm 0.43,4.60 \pm$ $1.51,9.09 \pm 1.04$, and $14.37 \pm 0.98 \mu \mathrm{g} / \mathrm{mL}$, respectively (Figure $1 \mathrm{~B}$ ).

The cinnamon essential oil at the concentrations of 125, 250, 500, and $1000 \mu \mathrm{g} / \mathrm{mL}$ significantly increased percentage of ABTS inhibition by $8.44 \pm$ $1.19,28.08 \pm 2.19,30.70 \pm 1.33$, and $50.17 \pm 3.95 \%$, respectively whereas cinnamon essential oil at the concentration of $62.5 \mu \mathrm{g} / \mathrm{mL}$ did not significantly increase the percentage of ABTS inhibition when compared with the contro groups (Figure 2A). The extent of inhibition of the absorbance of the ABTS •+ was plotted as a function of concentration in order to determine the Trolox Equivalent Antioxidant Capacity (TEAC). Cinnamon essential oil at the concentrations of $62.5,125,250,500$, and $1000 \mu \mathrm{g} / \mathrm{mL}$ showed the TEAC values as $4.74 \pm 0.82,7.07 \pm 0.80,20.29 \pm 1.47,22.01 \pm 0.90$, and $35.08 \pm 2.65 \mu \mathrm{g} / \mathrm{mL}$ respectively (Figure $2 \mathrm{~B}$ ). 
A

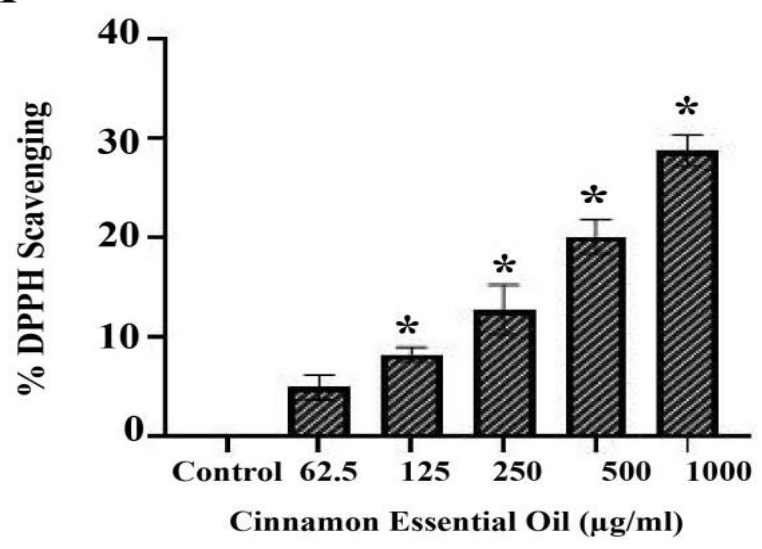

B

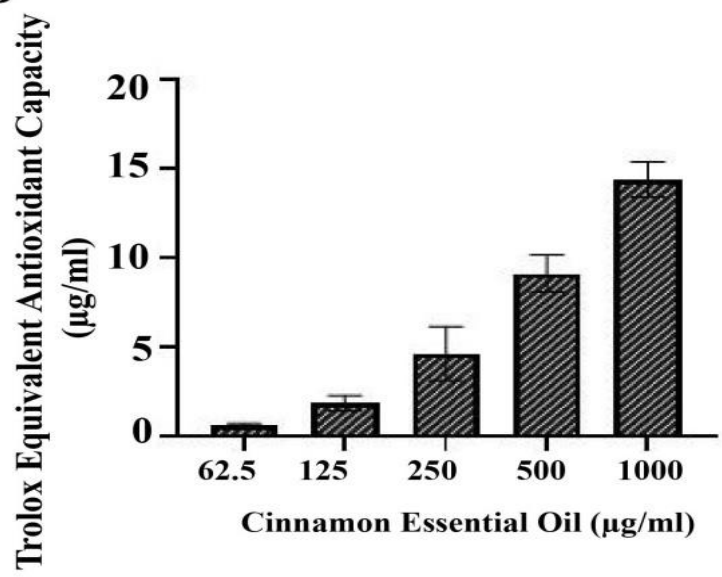

Figure 1 (A) The effect of the cinnamon essential oil on the percentage of DPPH scavenging and (B) The Trolox equivalent antioxidant capacity (TEAC) of the cinnamon essential oil. ( $* x<0.05$ compared with the control group)

A

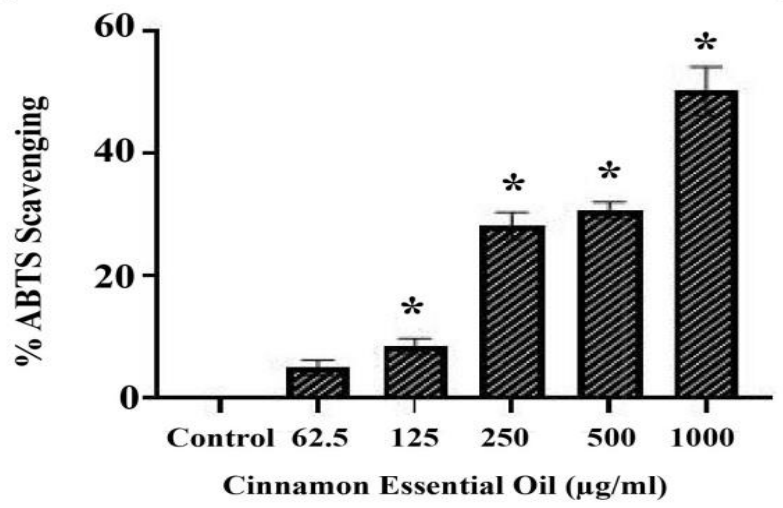

B

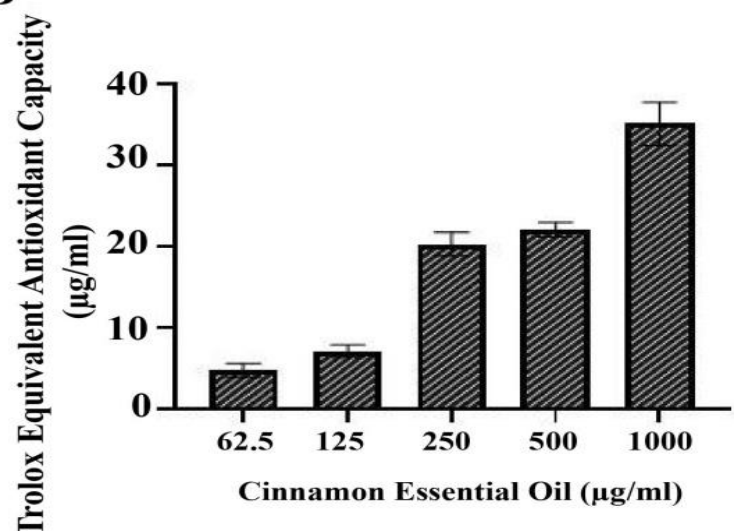

Figure 2. (A) The effect of the cinnamon essential oil on the percentage of ABTS scavenging and (B) The Trolox equivalent antioxidant capacity (TEAC) of the cinnamon essential oil. (* $p<0.05$ compared with the control group)

Free radicals are unstable atoms that can damage cells causing illness and aging. The characteristics of natural antioxidants are formed in a wide mechanism of actions. The individual experiment of antioxidant activity is incapable to cover all the antioxidant profile, thus different assays of antioxidant activity should be used (Brodowska et al., 2015). In this study, the cinnamon essential oil has showed an antioxidant activity in the dose-dependent manner by both DPPH and ABTS assays. The essential oil extract from the leaves of Cinnamomum zeylanicum are rich in eugenol, which is a phenolic compound that has great scavenging effect on DPPH and $\mathrm{OH} \bullet$ radicals (Schmidt et al., 2016). The phenolic compounds have been known to exhibit antioxidant properties by quenching free radical species through the loss of a hydrogen atom. It may be possible that eugenol is primarily responsible for the antioxidant activity of cinnamon essential oil in both DPPH and ABTS assays rather than cinnamaldehyde.

\section{Inhibition of tyrosinase, collagenase and elastase activities}

The inhibitory of enzyme activities of tyrosinase, collagenase and elastase were performed in this study. The cinnamon essential oil at the concentrations of 10 , $100,200,500$, and $1000 \mu \mathrm{g} / \mathrm{mL}$ significantly increased the percentage of tyrosinase inhibition activity by $23.15 \pm 1.71 \%, 59.27 \pm 2.32 \%, 77.06 \pm 6.95 \%$, $86.43 \pm 2.32 \%$, and $93.12 \pm 8.03 \%$, respectively when compared with the control group (Figure 3.).

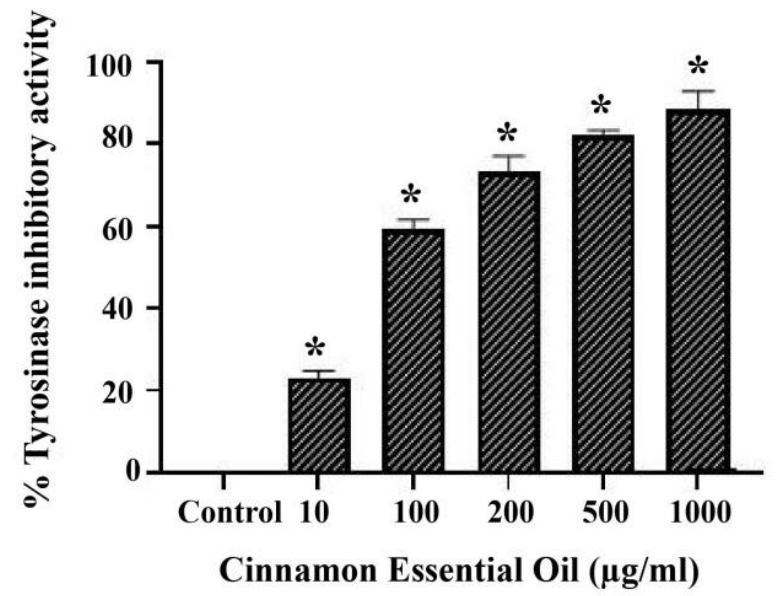

Figure 3 The inhibitory effect of cinnamon oil on tyrosinase activity. (* $p<0.05$ compared with the control group)

The cinnamon essential oil at the concentrations of 100, 200, 500, and 1000 $\mu \mathrm{g} / \mathrm{mL}$ significantly increased percentage of collagenase inhibition activity by $5.96 \pm 1.69 \%, 14.35 \pm 2.97 \%, 23.04 \pm 1.17 \%$, and $30.28 \pm 0.75 \%$, respectively when compared with the control group (Figure 4.). 


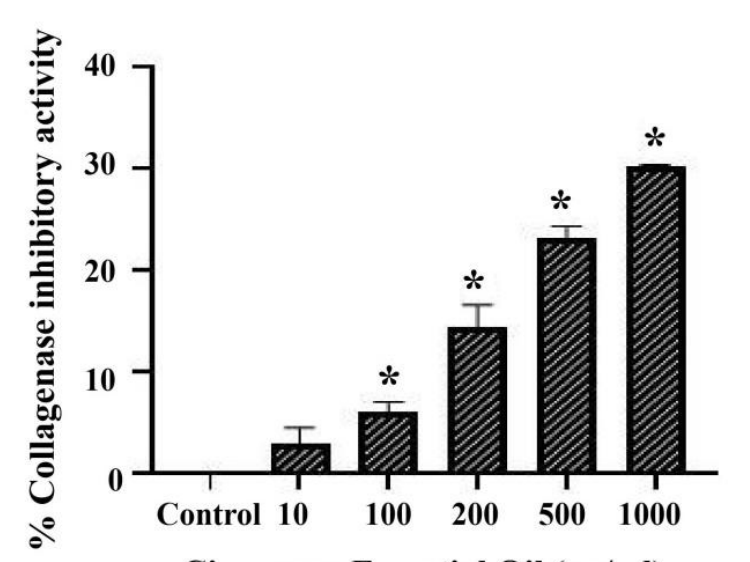

Cinnamon Essential Oil $(\mu \mathrm{g} / \mathrm{ml})$

Figure 4 The inhibitory effect of the cinnamon oil on the percentage of collagenase inhibition activity. (* $p<0.05$ compared with the control group)

The cinnamon essential oil at the concentrations of 10, 100, 200, 500, and 1000 $\mu \mathrm{g} / \mathrm{mL}$ significantly increased percentage of elastase inhibition activity by $4.37 \pm$

$1.54 \%, 6.87 \pm 0.48 \%, 12.63 \pm 0.79 \%, 21.70 \pm 1.15 \%$, and $33.92 \pm 0.39 \%$, respectively when compared with the control group (Figure 5.).

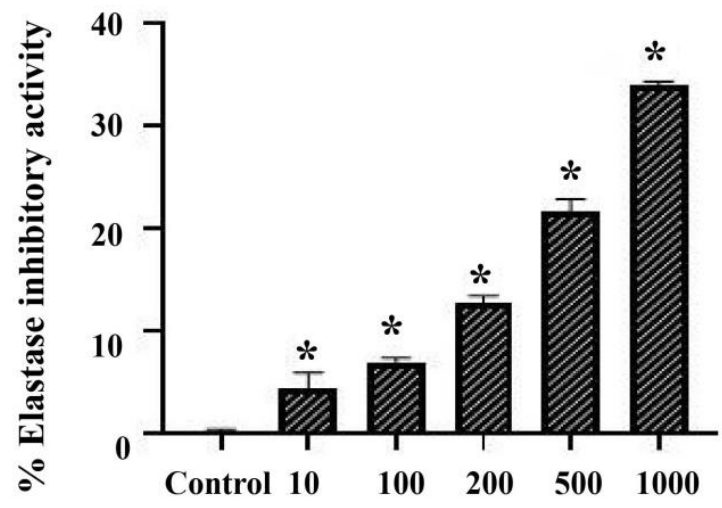

Cinnamon Essential Oil $(\mu \mathrm{g} / \mathrm{ml})$

Figure 5 The inhibitory effect of the cinnamon essential oil on the percentage of elastase inhibition activity. ( $* p<0.05$ compared with the control group)

The tyrosinase enzyme plays a major role in mammalian melanogenesis that generates more browning of the skin (Chang, 2019). Based on the findings in this study, the cinnamon essential oil showed the anti-tyrosinase activity which is supported by the previous reports (Lee et al., 2000; Marongiu et al., 2007; Ngoc et al., 2009). Moreover, Chou et al. (2013) demonstrated that the inhibition of $\alpha$ MSH-induced melanin production in melanoma cells was in a dose-dependent manner. The mechanism underlying this effect is still unclear but cinnamon essential oil is rich in cinnamaldehyde which may play an important role in the inhibition of tyrosinase activity and the production of melanin (Chang $\boldsymbol{e t}$ al., 2013). Since the increases of collagenase and elastase activities induced the degradation of the protein matrix and elastin resulting in aging, the anticollagenase and anti-elastase activities of cinnamon essential oil were also investigated in this study. The cinnamon essential oil showed the collagenase and elastase inhibitory activities. These results were supported by the study of Bharti et al. (2013). They found that the collagenase inhibitory activities from the aqueous extract, methanol extracts and essential oils extracts from Cinnamomum zeylanicum were $25 \%, 30 \%$ and 35\%, respectively. Furthermore, Aumeeruddy - Elalfia et al. (2018) reported that the cinnamon essential oil from Cinnamomum zeylanicum moderately inhibited collagenase and elastase activities. These may be partly due to the biosynthesis of collagenase type I promoting to the activation of IGF-1 (Takasao et al., 2012). Lee et al. (1999) reported that methanolic extract of Cinnamomum cassia causes inhibition of elastase activity at the concentrations of $100-1000 \mu \mathrm{g} / \mathrm{mL}$ and suggested that the phenolic compound content in this plant might be responsible for its effect. Moreover, the reduction in elastase activity has been observed in the essential oils from Cinnamomum verum containing eugenol and cinnamaldehyde as the major components.
Cytotoxicity assay

After exposure to the cinnamon essential oil at the concentrations of 10 and 100 $\mu \mathrm{g} / \mathrm{mL}$ for 24 hours, the percentage of cell viabilities of fibroblast cells were $100.67 \pm 1.57$ and $101.15 \pm 1.99 \%$, respectively which were not significantly different when compared with the control group. However, the cell viabilities were significantly decreased $(45.06 \pm 2.45,36.56 \pm 1.73$ and $31.29 \pm 1.83 \%$, respectively) when these cells were exposed to the cinnamon essential oil at the concentrations of 150, 200 and $400 \mu \mathrm{g} / \mathrm{mL}$ as shown in Figure 6.

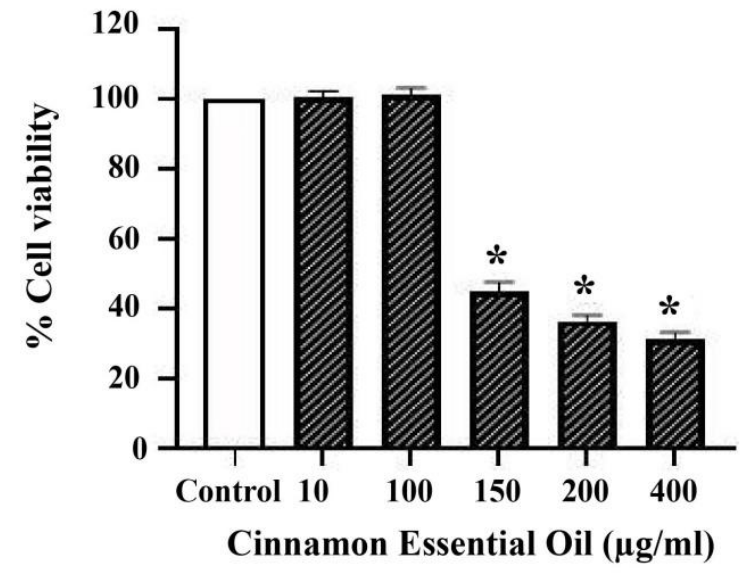

Figure 6 The effect of the cinnamon essential oil on the percentage of the cell viability of fibroblast following 24 hours of exposure. (* $p<0.05$ compared with the control group (untreated cells)

In vitro cytotoxicity assay was useful for screening of the cytotoxic potential of substances. The effect of the cinnamon essential oil on normal human fibroblast cells, which is one type of the skin cells, was investigated in this study. The result of cell viability assay showed that the cinnamon essential oil at the concentration less than $100 \mu \mathrm{g} / \mathrm{mL}$ had no cytotoxic effect on normal human fibroblast cells whereas cytotoxic effect was seen when the concentration of $150 \mu \mathrm{g} / \mathrm{mL}$ was applied. The previous report showed that the cytotoxicity of the cinnamon essential oil from Cinnamomum zeylanicum was quite strong with $\mathrm{IC}_{50}$ values less than $20 \mu \mathrm{g} / \mathrm{mL}$ for 5RP7 (H-ras active-rat fibroblasts) and F2408 (normal rat fibroblasts) cells (Unlu et al., 2010). The result of this study demonstrated that cinnamon essential oil is less toxic when compared with previous researches. The results may vary due to chemical compounds extracted as well as the different species of these plants. However, the cytotoxic effect should be further investigated in other types of skin cells and active-compounds, and conducted in in vivo experiment.

\section{CONCLUSION}

Based on the results of antioxidant activity, tyrosinase inhibitory activity, collagenase inhibitory activity, and elastase inhibitory activity of the cinnamon essential oil, this oil may be a potential candidate to use as an ingredient in skin whitening and/or anti-skin aging agents in cosmetic and pharmaceutical industries. However, the underlying mechanism for biological activities should be further investigated. Besides in vitro test in this study, both in vivo and clinical studies should be further conducted to explore the therapeutic properties, formulation and safety.

Acknowledgments: This study was supported by the funding from the Biomedical Sciences Graduate Program, Department of Medical Science, Faculty of Science, Rangsit University. We thank the Department of Medical Science, Faculty of Science, Rangsit University for laboratory facilities.

\section{REFERENCES}

Aumeeruddy-Elalfia, Z., Lallb, N., Fibrichb, B., Stadenb, A.B.V., Hosenallyc M., \& Mahomoodally, M.F. (2018). Selected essential oils inhibit key physiological enzymes and possess intracellular and extracellular anti melanogenic properties In vitro. Journal of food and drug analysis, 26(1): 232 243. https://doi.org/10.1016/j.jfda.2017.03.002

Bharti, P., Seasotiya, L., Bai, S., Malik, A., \& Dalal, S. (2013). Antibacterial, antioxidant, collagenase inhibition, urease inhibition activities and chemical of the essential oil and extracts of Cinnamomum zeylanicum bark. International journal of phytomedicine, 5(1).

Brodowska, A.J., Smigielski, K., Nowak, A., Czyzowska, A., \& Otlewska, A. (2015). The impact of ozone treatment in dynamic bed parameters on changes in biologically active substances of juniper berries. PLOS ONE, 10(12) https://doi.org/10.1371/journal.pone.0144855 
Chang, T.S. (2009). An updated review of tyrosinase inhibitors. International journal of molecular sciences, 10(6): 2440-2475. https://doi.org/10.3390/ijms10062440

Chang, C.T., Chang, W.L., Hsu, J.C., \& Shih, Y. (2013). Chemical composition and tyrosinase inhibitory activity of Cinnamomum cassia essential oil. Botanical Studies, 54(10): 2-7. https://doi.org/10.1186/1999-3110-54-10

Chou, S.T., Chang, W.L., Chang, C.T., Hsu, S.L., Lin, Y.C., \& Shih, Y. (2013) Cinnamomum cassia Essential Oil Inhibits $\alpha$-MSH-Induced Melanin Production and Oxidative Stress in Murine B16 Melanoma Cells. International Journal of Molecular Sciences, 14(9): 19186-19201. https://doi.org/10.3390/ijms140919186 Eicken, C., Zippel, F., Büldt-Karentzopoulos, K., \& Krebs, B. (1998) Biochemical and spectroscopic characterization of catechol oxidase from sweet potatoes (Ipomoea batatas) containing a type-3 dicopper center. FEBS Letters, 436: 293-299. https://doi.org/10.1016/S0014-5793(98)01113-2

Farage, M.A., Miller, K.W., Elsner, P., \& Maibach, H.I. (2008). Intrinsic and extrinsic factors in skin ageing: a review. International Journal of Cosmetic Science, 30(2): 87-95. https://doi.org/10.1111/j.1468-2494.2007.00415.x

Gruenwald, J., Freder, J., \& Armbruester, N. (2010). Cinnamon and health Critical Reviews in Food Science and Nutrition, 50(9): 822-34. https://doi.org/10.1080/10408390902773052

Gulcin, I., Kaya, R., Goren, A.C., Akincioglu, H., Topal, M., Bingol, Z. Cakmak, K.C., Sarikaya, S.B.O., Durmaz, L. \& Alwasel, S. (2019). Anticholinergic, antidiabetic and antioxidant activities of cinnamon (Cinnamomum verum) bark extracts: polyphenol contents analysis by LCMS/MS. International Journal of Food Properties, 22(1): 1511-1526. https://doi.org/10.1080/10942912.2019.1656232

Han, X., \& Parker, T.L. (2017). Antiinflammatory Activity of Cinnamon (Cinnamomum zeylanicum) Bark Essential Oil in a Human Skin Disease Model. Phytotherapy Research, 31(7): 1034-1038. https://doi.org/10.1002/ptr.5822

Lee, K.K., Kim, J.H., Cho, J.J., \& Choi, J.D. (1999). Inhibitory Effects of 150 plant extracts on elastase activity, and their anti-inflammatory effects. International Journal of Cosmetic Science, 21: 71-82. https://doi.org/10.1046/j.1467-2494.1999.181638.x

Lee, O.H., \& Lee, B.Y. (2010). Antioxidant and antimicrobial activities of individual and combined phenolics in Olea europaea leaf extract. Bioresource Technology, 101(10): 3751-4. https://doi.org/10.1016/j.biortech.2009.12.052

Lee, S.E., Kim, M.K., Lee, S.G., Ahn, Y.J., \& Lee, H.S. (2000). Inhibitory effects of Cinnamomum cassia bark-derived materials on mushroom tyrosinase. Food Science and Biotechnology, 9: 330-333.

Lesgards, J.F., Baldovini, N., Vidal, N., \& Pietri, S. (2014). Anticancer Activities of Essential Oils Constituents and Synergy with Conventional Therapies: A Review. Phytotherapy Research, 28(10). https://doi.org/10.1002/ptr.5165

Lin, C.C., Wu, S.J., Chang, C.H., \& Ng, L.T. (2003). Antioxidant activity of Cinnamomum cassia. Phytotherapy Research,17: 726-730.

https://doi.org/10.1002/ptr.1190

Marongiu, B., Piras, A., Porcedda, S., Tuveri, E., Sanjust, E., Meli, M., Sollai, F., Zucca, P., \& Rescigno, A. (2007). Supercritical CO2 extract of Cinnamomum zeylanicum: chemical characterization and antityrosinase activity. Journal of Agricultural and Food Chemistry, 55: 10022-10027. https://doi.org/10.1021/jf071938f

Ngoc, T.M., Lee, I., Ha, D.T., Kim, H., Min, B., \& Bae, K. (2009). Tyrosinase inhibitory constituents from the twigs of Cinnamomum cassia. Journal of Natural Products, 72: 1205-1208. https://doi.org/10.1021/np900031q

Nyadjeu, P., Dongmo, A., Nguelefack, T.B., \& Kamanyi, A. (2011) Antihypertensive and Vasorelaxant Effects of Cinnamomum zeylanicum Stem Bark Aqueous Extract in Rats. Journal of Complementary and Integrative Medicine, 1; 8(1): 1-18. https://doi.org/10.2202/1553-3840.1490

Re, R., Pellegrinia, N., Proteggente, A., Pannala, A., Yang, M., \& Rice-Evans, C. (1999). Antioxidant activity applying an improved ABTS radical cation decolorization assay. Free Radical Biology and Medicine, 26: 1231-1237. https://doi.org/10.1016/S0891-5849(98)00315-3

Schmidt, E., Jirovetz, L., Buchbauer, G., Eller, G.A., Stoilova, L., Krastanov, A., Stoyanova, A., \& Geissler, M. (2016). Composition and antioxidant activities of the essential oil of cinnamon (Cinnamomum zeylanicum Blum) leaves from Sri Lanka. Journal of Essential Oil Bearing Plants, 9(2): 170-182. https://doi.org/10.1080/0972060X.2006.10643490

Shaaban, H.A., \& El-Ghorab, A.H. (2012). Bioactivity of essential oils and their volatile aroma components: Review. Journal of Essential Oil Research, 24(2): 203-212. https://doi.org/10.1080/10412905.2012.659528

Stevenson, S., \& Thornton, J. (2007). Effect of estrogens on skin aging and the potential role of SERMs. Journal of Clinical Interventions in Aging, 2(3): 283297. https://doi.org/10.2147/CIA.S798

Takasao, N., Tsuji-Naito, K., Ishikura, S., Tamura, A., \& Akagawa, M. (2012). Cinnamon extract promotes type I collagen biosynthesis via activation of IGF-I signaling in human dermal fibroblasts. Journal of Agricultural and Food Chemistry, 60: 1193-200. https://doi.org/10.1021/jf2043357

Unlu, M., Ergene, E., Unlu, G.V., Zeytinoglu, H.S., \& Vural, N. (2010). Composition, antimicrobial activity and In vitro cytotoxicity of essential oil from Cinnamomum zeylanicum Blume (Lauraceae). Food and Chemical Toxicology, 48(11): 3274-80. https://doi.org/10.1016/j.fct.2010.09.001
Varalakshmi, B., Anand, A.J., Karpagam, T., Bai, J.S.., \& Manikandan, R. (2014). In vitro antimicrobial and anticancer activity of Cinnamomum Zeylanicum linn bark extracts. International Journal of Pharmacy and Pharmaceutical Sciences, 6(1): 12-18.

Yagi, M., \& Yonei, Y. (2018) Glycative stress and skin aging. Glycative Stress Research, 5(1): 050-054. http://doi.org/10.24659/gsr.5.1_50 